\title{
David Against Goliath: Predicting The Survival Of Formal Small Businesses In Soweto
}

Johan Strydom, University of South Africa, South Africa

\begin{abstract}
The aim of the paper is to determine empirically through quantitative research the key characteristics for survival of formal small businesses in the Soweto Township area. The focus was on the formal small businesses that have been operating in a very dynamic business environment with the introduction of modern shopping facilities during this period. Binary logistic regression was used to develop two regression models to predict the survival of formal small businesses based on the key characteristics identified in the literature study. The results indicate survival similarities between formal and informal small businesses regarding longevity of the business, better qualifications of owners/managers, greater maturity of owners/managers and being further away from the new shopping malls. Even with the drastic changes in the business environment of formal small businesses in Soweto, there were a group of small businesses that were able to survive and grow. Information regarding this group of small businesses can be of value to owners and investors in their future consideration of venturing and funding new small businesses in the township areas of South Africa.
\end{abstract}

Keywords: Formal Small Businesses; Informal Small Businesses; Soweto; Business Survival; Binary Logistic Regression

\section{INTRODUCTION}

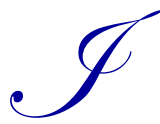

$\mathrm{n}$ the past two decades drastic changes have occurred in the business environment of the previouslydisadvantaged townships of South Africa. Moving from an unplanned business infrastructure consisting of scattered formal and informal businesses, these townships have graduated to state-of-the art shopping malls with an impressive array of national retailers and all the largest brand name shops in South Africa available.

Making use of these shopping mall developments has brought major successes for the Goliath national retailers such as Shoprite and Pick n Pay, with Soweto customers flocking to these malls to spend money in firstworld business facilities. Malls and retailers have also benefitted from higher disposable incomes that have been generated by residents of Soweto as the black middle-class continues to grow in the township (Burger, 2013).

This influx of large retail businesses and the development of malls such as the Jabulani, Bara and Maponya malls have also had some consequences on the existing retailing and general business infrastructure of Soweto. With the shift in patronage to the large retailers by Sowetan consumers, the existing formal and informal small businesses bore the brunt of changes in shopping patterns and displaced customer loyalty, resulting in the closure of small businesses. The decline of these David-sized formal and informal small businesses was investigated in various studies carried out by Ligthelm since the inception of the shopping malls in Soweto (Ligthelm, 2005, 2006, 2008, 2010), culminating in the authorative 2011 report wherein Ligthelm profiled successful informal small businesses that were still operating five years after the establishment of these large shopping malls in Soweto.

The research objective of this study is to use the information gathered by Ligthelm and to focus specifically on the survival of the formal small businesses formats in the township. The aim is to test the profile criteria that 
were developed by Ligthelm for the informal sector with the research results obtained from the formal small businesses and to ascertain if the survival profile for the informal small businesses also holds true for the formal small businesses of Soweto. It furthermore aims to predict the chances of survival of these small formal businesses in this area.

\section{Definition Of Concepts}

Before commencing with the background discussion, the concepts of a small business, a formal small business and informal small business will first be elucidated.

There are various definitions of what a small business is in South Africa. One such definition of a small business is described in The National Small Business Amendment Act of the Republic of South Africa (2003) which states that a small enterprise in the retail industry is an entity that has a staff headcount of up to 50 people, an annual turnover of up to R19 million and a total gross asset value of up to R3 million (National Small Business Amendment Act of the Republic of South Africa, 2003).

For the purposes of this study, a township small business will be defined as "a business with a permanent superstructure (usually brick and mortar), located either in the demarcated business areas of Soweto as well as in the residential areas of the township, and which employs fewer than ten employees on a full- and part-time basis" (Ligthelm, 2008:52).

Lastly, a distinction must also be made between a formal and an informal small business. According to Du Plessis, Strydom and Jooste (2012), formal small businesses are those businesses that are located in purpose-built shops and form part of the registered business infrastructure of South Africa, thus paying taxes and the required levies to the various levels of government. Informal small businesses, on the other hand, are described by Du Plessis et al as being involved with subsistence-level business activities, that are not located in a dedicated business infrastructure and are not registered with the respective government structures and do not necessarily pay the relevant taxes to government. Ligthelm (2012) concurs with this description, stating that the informal small businesses investigated in Soweto produce and sell goods and services that are unregistered or hidden from state scrutiny for tax purposes. For the purposes of this article, formal small businesses will include formal small retailers and the two terms will be used interchangeably.

\section{Overview Of The Small Business Environment Of Soweto}

The South African small business environment and especially the retailing environment have seen dramatic reform during the past two decades, mostly owing to government changes to open up the economy. These changes have been eagerly anticipated by the large retailing groups in South Africa, which led to an influx of the large retailing groups such as Shoprite and Pick $\mathrm{n}$ Pay into the under-serviced townships. This move was also widely welcomed by consumers living in these areas which were previously disadvantaged, with poor retailing facilities due to structural problems inherited from the previous socio-political dispensation. Previously, small township businesses struggled to survive and consumers were under-serviced with only rudimentary retail services being provided (Strydom, Martins, Potgieter and Geel, 2002).

Research showed that the majority of formal businesses in townships were clustered in small, formal neighbourhood centres and consisted of predominantly small retailers. Most of the retailers were classified as general retailers selling groceries, but there were also numerous informal retailers competing with the formal retailers in these areas. These informal retailers included spaza shops (convenience retailers operating from a room in a house), hawkers (selling mostly perishable products) and shebeens (selling beer and other forms of liquor).

Further to the reasons for changes to the Soweto business environment, the nascent development of the township business infrastructure can be ascribed to governmental encouragement to institutional investors to invest in the townships. This was done to fulfill the aims of the presidential renewal programme to develop new infrastructures in rural and under-serviced township areas. Coupled to this was the growing evidence of the increase in spending power of African consumers during the past two decades (Tustin and Strydom, 2006). In the period 
from 1998 to 2008, the South African economy had seen dramatic progress in the living standards of the township dwellers and there was a rapid improvement in household income (Ligthelm, 2008, and Ligthelm, 2010). A study by the United Nations shows that there is a surge towards urbanisation which has resulted in growth opportunities for the South Africa retailing industry. More than $64 \%$ of the South African population is anticipated to be residing in the urban areas by 2015 (Thomas White, 2011).

The South African retail industry is viewed as the largest in the sub-Saharan region and is globally ranked as the 20th largest retail market in the world. A report in 2011 indicated that South African large retailers are competing in an oligopolistic market with five South African corporate groups, namely Shoprite, Pick n Pay, Spar, Massmart and Metcash, responsible for $80 \%$ of all wholesale and retail sales (Thomas White, 2011). There is speculation that the large retailers' foray into the townships may have been a contributing factor in the collapse of one of the biggest wholesale business operations in Africa, namely Metcash. The Metcash business model focused on informal small businesses such as street vendors and spaza shops that purchased mainly from cash-and-carry-type Metcash stores. As more and more of these informal business retailers were forced to close due to the incursions of the large formal retailers into the townships, Metcash lost its downstream distribution channel outlets (small grocery businesses). In what can be seen as a confirmation of the fundamental changes in the township retailing sector, cashand-carry wholesaling which for decades provided the necessary supply chain to source informal small businesses collapsed due to the invasion of the shopping malls by the large retailers in the townships (Vallie, 2012).

Large shopping developments in townships such as the Jabulani, Bara and Maponya malls are dependent on a large customer base and on attracting sustainable anchor tenants such as national grocery retail chains offering a full range of perishable and non-perishable grocery items to Sowetan residents. The products presented by these large retailers are similar to those presented by the small formal and informal small businesses in the township and create what is classified as an intratype competitive situation (Levy and Weitz, 2012). The development of the shopping malls and the retailing store mix in these malls led to the resultant increased competition and the demise of both formal and informal grocery retailers residing in all areas of Soweto.

Another consequence of the changes occurring in Sowetan township businesses was the increased focus on the plight of the informal business sector in the townships, especially the spaza shops that were investigated by various researchers. See in this regard the longitudinal studies done by Ligthelm (2004, 2005, 2006, 2008, 2010 and 2012) and other researchers such as Strydom (2005), Tustin and Strydom (2006), Van Scheers (2010) and Woodward, Rolfe, Ligthelm and Guimarães (2011). Most of these research findings established that the informal small businesses are marginalised with a small contribution to GDP, while catering for a growing portion of the unemployed population. It also concludes that these informal retailers are far removed from formal sector business practices and applications and create a minimal number of jobs, while being incapable of generating growth and development opportunities for the country (Ligthelm, 2013). As such, they are perceived to be unproductive or survivalist entrepreneurs whose main aim is to prevent themselves from sliding deeper into poverty. Berner, Gomez and Knorringa (2008) state that government and private sector policies aimed at stimulating unproductive entrepreneurs such as these in the informal business sector are ineffective.

Ligthelm (2012) reported on a five-year longitudinal study on the informal small business sector (also called micro businesses) in the Soweto Township where the survivalists in the informal business sector were tracked. Findings of this study indicate that having entrepreneurial acumen was a significant, positive factor for business survival. The positive entrepreneurial actions of these survivalists by means of, inter alia, the regular investigation of alternative business investments, and especially the seizing of business opportunities, was recognised. Actions such as using a business plan prior to the establishment of the business and the regular analysis of competitors also confirmed an entrepreneurial mindset. Some of the predictors for business survival from this study amongst informal small businesses include the following (Ligthelm, 2012):

- $\quad$ Age Of The Business: The age of the business refers to the experience of the marketplace, maturity of the business in its life cycle and the experience of the owner in managing the business through trying economic circumstances. In essence, it was found that the longer the business had been in operation, the better its chances for success and survival.

- Location: The right location of the business was also found to be important. A positive relationship for 
survival was identified between the location of a retailer in a more formalised business area. The opposite was also established, with a poor location resulting in less chance for survival in places such as in-home businesses. Coupled to this is also the pre-requisite that these informal small businesses be serviced with the proper infrastructure such as reticulation, electricity and accessible roads.

- $\quad$ Financial Recordkeeping: Informal businesses that keep track of business activities such as financial records, do budgeting, prepare cash flow statements and have procurement documentation have a higher proclivity for survival.

- $\quad$ Turnover: Higher turnover levels result in higher levels of sustainability. The majority of these high turnover informal businesses were identified as being run by opportunity-driven entrepreneurs instead of necessity-driven entrepreneurs. Necessity entrepreneurs or unproductive entrepreneurs are people that are forced into entrepreneurship activities because of a lack of economic choices or who are using entrepreneurial activity as an instrument for survival or escaping from a situation of unemployment and poverty. Berner, Gomez and Knorringa (2008: 1) state that the motivation for these types of entrepreneurs is not growth, but survival. On the other hand, opportunity or productive entrepreneurs are voluntarily involved and aim to exploit potentially profitable business opportunities with an opportunity for growth and self-fulfillment (Ligthelm, 2010).

- $\quad$ Education Levels: Higher educational qualifications of owners usually result in higher levels of growth and sustainability of their businesses.

- Maturity: Older or more mature retail owners have a higher chance of survival than younger business owners.

- $\quad$ Competition: Heightened level of competition between informal businesses and formal businesses has a major negative effect on the business survival of the informal retailers.

Having looked at the characteristics and profile of the informal small businesses as well as the predictors for survival, it is also necessary to investigate global and domestic research undertaken on the survival of formal small businesses.

\section{Predictors For Survival For Formal Small Businesses} businesses:

A literature research delivered the following key predictors regarding the survival of formal small

- $\quad$ Reijonen and Komppula (2007) state that in Finland, one of the measures of survival and ultimately the success of small businesses resides in size of turnover, number of employees and amount of the market share and profits realised. These authors, however, caution against the use of financial measurement as the sole predictor for survival.

- $\quad$ Blackburn, Hart and Wainwright (2013) found in the UK that older small businesses that had a written business plan, were involved in consumer services and were run by owners who considered themselves to be innovative, were more likely to be successful. Ligthelm (2012) evidenced this also for the formal small businesses in Soweto.

- $\quad$ The finding of studies by Tushabomwe-Kazooba (2006), Ihua (2009) and Okpara (2011) in Nigeria, Blackburn, Hart and Wainwright (2013) in the UK and Van Scheers (2010) in South Africa reflects that poor financial recordkeeping and a lack of basic business management skills (such as not having a business plan and not being innovative) are major reasons for small business failure.

- $\quad$ Ejembi and Ogiji (2007) and Mbonyane and Ladzani (2011) indicate that in Nigeria and South Africa, poor location such as a lack of infrastructure in the form of poor roads, limited reticulation and unreliable electricity supply can have a debilitating effect on the survival of formal small businesses.

- Nkosi and Bounds (2012) researched the skills that have contributed to the survival of small businesses in Soweto and especially those who have been in operation for five years or more. Nkosi and Bounds (2012) found that the age (maturity) of the owner or manager was an important indicator for the survival of the business, with being more mature providing a better chance of survival. They also found that higher levels of education of the owner/manager have a positive correlation with the survival of small businesses in Soweto. 
- $\quad$ Abrahams (2009), Van Scheers (2010) and Okpara (2011) mention that increased competition was one of the major problems faced by small businesses in Africa and in South Africa. Increased competition results in less demand for products and services of these small businesses, which negatively impacts on the financial situation of these businesses. Abrahams (2009) adds to the debate by looking more holistically at the impact of large South African retailers on African retailing. South African retailers such as Shoprite and Pick n Pay have been expanding beyond South African borders for more than two decades and are obtaining a major share of their profits from outside South Africa. He states that the large South African retailing groups are not solely responsible for the demise of the small grocery retailers in African countries where they compete, but that urbanisation of the population and centralisation of the large retailers resulted in local small retailers being outcompeted in the African marketplace.

- $\quad$ Ligthelm (2004), Woodward, Rolfe, Ligthelm \& Guimarães ( 2011) and Nkosi and Bounds (2012) all postulated that South African small formal grocery retailers have a better chance of survival after a period of five years in operation.

To summarise the theoretical discussion, the following key predictors regarding the survival of the formal and informal small business can be juxtaposed (see Table 1).

Table 1. Predictors For Survival (Informal Versus Formal Small Businesses)

\begin{tabular}{ll}
\hline \multicolumn{1}{c}{ Informal Small Business } & \multicolumn{1}{c}{ Formal Small Business } \\
\hline $\begin{array}{l}\text { Age of business - the longer in existence, the more } \\
\text { chance for survival (Ligthelm, 2012). }\end{array}$ & $\begin{array}{l}\text { Age of business - the longer the duration of existence, the more } \\
\text { chance for success (Blackburn, Hart and Wainwright, 2013 and } \\
\text { Ligthelm, 2012). }\end{array}$ \\
\hline Good location of the business (Ligthelm, 2012). & $\begin{array}{l}\text { Good location of the business (Ejembi and Ogiji, 2007 and } \\
\text { Mbonyane and Ladzani, 2011). }\end{array}$ \\
\hline $\begin{array}{l}\text { Keeping financial records (Ligthelm, 2012), also } \\
\text { referred to as keeping track of business activities. }\end{array}$ & $\begin{array}{l}\text { Keeping track of business activities such as having financial } \\
\text { records, plus business management skills such as having business } \\
\text { plans and being innovative (Tushabomwe-Kazooba, 2006; Ihua, } \\
\text { 2009; Okpara, 2011, Blackburn, Hart and Wainwright, 2013 and } \\
\text { Van Scheers, 2010). }\end{array}$ \\
\hline $\begin{array}{l}\text { Educational levels - higher levels lead to a greater } \\
\text { chance of success (Ligthelm, 2012). }\end{array}$ & $\begin{array}{l}\text { Educational levels - the higher the level, the greater the chance of } \\
\text { success (Nkosi and Bounds, 2012). }\end{array}$ \\
\hline $\begin{array}{l}\text { Age (maturity) of the owner - the older the owner, the } \\
\text { better the chance of survival (Ligthelm, 2012). }\end{array}$ & $\begin{array}{l}\text { Age of the owner - the older the owner, the better the chance of } \\
\text { survival (Nkosi and Bounds, 2012). }\end{array}$ \\
\hline $\begin{array}{l}\text { Level of competition - less competition provides a } \\
\text { better chance for survival (Ligthelm, 2012). }\end{array}$ & $\begin{array}{l}\text { Level of competition - less competition provides a better chance for } \\
\text { survival (Abrahams, 2009; Van Scheers, 2010 and Okpara, 2011). }\end{array}$ \\
\hline
\end{tabular}

As can be seen from the literature summarised in Table 1, there is a major overlap between the survival criteria of the informal and formal small businesses.

\section{Problem Statement}

Various researchers have reported on the high rate of failure amongst small formal businesses in South Africa. Moodie (2003) and Van Eeden, Viviers and Venter (2003) state that $80 \%$ of South African small businesses fail within five years of commencing business. Giliomee (2004) adds that of the $20 \%$ that survive the first five years, nearly four out of five fail within the next five years, resulting in only a $4 \%$ survival rate over a period of ten years. This type of attrition is also occurring in the Soweto Township, with the added threat of competition from the expansion of large supermarkets and malls in the township area presenting a threat of survival for these small businesses (Makholwa 2014). Township customers who supported small grocery retail shops in the past, primarily due to their convenient location and product breakdown in smaller quantities (convenience store operational model), have deserted these small businesses. They are now supporting the supermarkets and malls that offer more product variety and lower prices, partly due to their increasing affluence and higher mobility (Ligthelm, 2008 and Chiliya, Herbst and Roberts-Lombard, 2009). The research question that arises focuses on the survival of the formal small business retailers that operate in the Soweto Township, given the entry of the large shopping malls and large retailers and, furthermore, to predict the chances of survival of these small formal businesses by using binary logistic regression models. 


\section{RESEARCH DESIGN AND METHODOLOGY}

The research identifies and analyses the key characteristics and dynamics of these formal small businesses in Soweto. Furthermore, the research was aimed at predicting the survival of formal small businesses located in formal business sites in Soweto.

\section{Study Area}

The survey area included all demarcated business areas/stands in Soweto, implying that only formal small businesses formed part of the research population. These business areas include shopping malls, large shopping areas (outside shopping malls), all the smaller shopping areas, single demarcated business stands and industrial areas.

\section{Survey Population}

Sample Units

The population of the survey comprised all the formal small businesses located in Soweto. Formal small businesses may be regarded as that part of the economy where businesses operate with fairly well-developed business management processes and financial and technological systems. To be considered as part of the sample, small businesses had to conform to the following prerequisites:

- $\quad$ Be an independent business with any of the following ownership structures: sole proprietor, partnership, cooperative, CC (close corporation) or a company.

- $\quad$ Be located on dedicated business premises.

- $\quad$ Conduct the business from a fixed cement and mortar structure.

The following businesses were excluded from the sample:

- $\quad$ Branches of all national chains such as Edgars Stores, Shoprite, Pick n Pay, Woolworths and Clicks.

- $\quad$ Franchise businesses of international business groups such as McDonalds and other national franchisors such as Battery Centre, Bimbo's, Butterfield Bakery, Debonairs Pizza, Fruit and Veg City, King Pie, Mugg and Bean and PG Glass.

- $\quad$ Street vendors/hawkers on pavements and in large informal markets at transport interchanges such as train and bus stations and taxi ranks in the Soweto area.

- In-home informal businesses in residential areas of Soweto such as spaza and tuck shops.

- $\quad$ Professional and business services such as dentists, accountants, attorneys and real estate agencies in Soweto.

- $\quad$ Transport businesses such as passenger bus transport and taxis.

Sample Elements

The sample elements in each of the selected businesses comprised either the owner or manager of the business, since the level of business acumen ingrained could only be discovered from the person responsible for the business decisions.

Sample Plan Design

Sampling Methodology

Since no list of small businesses operating in the study area was available, a multi-stage quota sample design was followed. The total sample was allocated according to the following segments: 
- $\quad$ Inside the large shopping malls

- $\quad$ Other shopping centres (outside the large malls). Shopping centres in the study area were selected at random and at least 50 businesses were to be interviewed in each of the following segments:

$\circ \quad$ Shopping centres with between 2 to 5 businesses in the shopping centre (micro shopping centres). No more than two businesses were interviewed in each of these centres. Stand-alone shops were also included in this segment. The business either to the left or right of the selected business was regarded as a substitute.

○ Shopping centres with between 6 and 10 businesses (very small shopping centres). Any business was selected at random and then every second business thereafter.

- Shopping centres with between 11 and 20 businesses in the centre (small shopping centres). Any business was selected at random and then every third business thereafter.

○ Shopping centres with more than 20 businesses in the centre (medium shopping centres). Any business was selected at random and then every third business thereafter.

Due to the small number of shopping centres with more than ten businesses in Soweto (small shopping centres), the quotas allocated to shopping centres with between 11 and 20 businesses and with more than 20 businesses (medium shopping centres) were not attained.

Industrial areas were identified and at least 50 manufacturers were interviewed in these areas. Due to the relatively small number of industrial businesses in the study area, all respondents willing to participate were interviewed.

\section{Sample Size}

The sample size was set at 653 businesses. The 653 businesses will also be regarded as the business panel for future research, with a view to establishing longitudinal trends in formal small business survival and attrition. No fewer than $96.9 \%$ of respondents confirmed their willingness to participate in future longitudinal surveys.

\section{Research Instrument}

The research instrument used enquired about the following aspects:

- $\quad$ nature of business

- $\quad$ physical characteristics of the business and the location

- $\quad$ internal operations, including business administration, financial/planning and competition

- demographical information of the respondent

\section{Processing Of Data}

Questionnaires were checked thoroughly for inconsistencies and omissions. Most questions were precoded. Captured data were processed and analysed through the SPSS package.

\section{RESULTS OF THE STUDY}

The total number of respondents to the study was 653. The descriptive results will first be discussed:

\section{Descriptive Statistics}

The demographic profile of the respondents are first provided by educational level, followed by age of owner/manager, their business turnover trend for the previous financial year and the average annual turnover per area surveyed (see Table 2). 
Table 2. Profile Of Small Business Owners/Managers

\begin{tabular}{lc}
\hline Profile & Percentage (\%) \\
\hline Educational Level & $\mathbf{1 0 0 . 0}$ \\
\hline No schooling & 0.9 \\
Grades 1-6 & 12.0 \\
Grades 7-12 & 54.8 \\
Technical/trade - less than 3 years & 20.9 \\
College/University - 3 years or more & 11.4 \\
\hline Age Of Owner & 14.5 \\
\hline $19-30$ years & 29.3 \\
$31-40$ years & 31.4 \\
$41-50$ years & 17.1 \\
$51-60$ years & 7.7 \\
61> years & \\
\hline Movement In Turnover Year Preceding Survey & $55.2 \%$ \\
\hline Expanded & $12.2 \%$ \\
Contracted & $32.6 \%$ \\
Same & \\
\hline Average Annual Turnover Per Specific Area Surveyed & $\mathrm{R} 271400$ \\
\hline Shopping Malls & $\mathrm{R} 254000$ \\
Stand-alone shops & $\mathrm{R} 271300$ \\
Micro shopping centre (2-5 businesses) & $\mathrm{R} 323400$ \\
Very small shopping centre (6-10 businesses) & $\mathrm{R} 356800$ \\
Small shopping centre (>10 businesses) & $\mathrm{R} 274800$ \\
Industrial areas & $\mathrm{R} 283900$ \\
Average turnover over all geographic locations & \\
\hline
\end{tabular}

The majority of the respondents' reported educational levels were at or below Grade 12 . The single largest group of respondents was in the 41 to 50 age category $(31,4 \%)$ with $60,7 \%$ of the total respondents in the age category 31 to 50 years. A majority of 55, 2\% of the respondents have seen an increased turnover during the 2012 period, with $32,6 \%$ reporting the same turnover as the previous year. What is of interest is that formal small businesses in the large shopping malls were not doing that well in respect of annual turnover. In fact, it was in the older small shopping centres with more than 10 businesses where these formal small retailers were performing the best for annual turnover (R356 800), which was a 31,4\% improvement on those formal small retailers situated in the newer large shopping malls.

Regarding the distance from the new shopping malls and the number of years in business of the formal small business, the cross-tabulation provided the following information (see Table 3 ).

Table 3: Cross-Tabulation Between Duration In Business And Distance From New Shopping Malls

\begin{tabular}{|c|c|c|c|c|c|}
\hline \multirow{2}{*}{ Duration In Business } & \multicolumn{4}{|c|}{ Distance Between Business And New Shopping Malls } & \multirow[b]{2}{*}{ Total } \\
\hline & Less Than $1 \mathrm{Km}$ & $1 \geq 3 \mathrm{Km}$ & $3.1 \mathrm{Km} \geq 5 \mathrm{Km}$ & $>5.1 \mathrm{Km}$ & \\
\hline Less than 1year & 23 & 33 & 13 & 4 & 73 \\
\hline $1 \leq 3$ years & 31 & 52 & 16 & 14 & 113 \\
\hline $3 \leq 5$ years & 28 & 22 & 35 & 48 & 133 \\
\hline$\geq 5$ years & 43 & 107 & 62 & 97 & 309 \\
\hline Total & 125 & 214 & 126 & 163 & 628 \\
\hline
\end{tabular}

What is clear from Table 3 is that nearly $50 \%$ of the respondents that were in business for more than 5 years indicated that they were successful in surviving the threat of the new shopping malls. Also of interest was the sizeable group of formal small businesses that were positioned further away from the formal shopping malls, which leads to the follow-up question as to whether there was a relationship between the distances away from these new shopping malls and the potential for survival.

Using the criteria for survival as the dependent variable, as indicated in Table 3 above, the following results were determined using logistic regression: 


\section{Binary Logistic Regression Results}

This study aims to determine whether or not the independent variables discussed above in the theoretical discussion and summarised in Table 1 (age or maturity of the owner, level of education of owner, distance from large shopping malls, keeping track of business activities [tracking], the extent to which local competitors influence the continued existence of the small business and the extent to which the large shopping malls exerts an influence on them) are statistically-significant predictors of the survival of formal small businesses in Soweto (dependent variable).

Two survival variables were identified and tested separately, namely:

- $\quad$ Formal small businesses in existence for more than five years, which refers to the period before or at the inception of the new shopping malls in Soweto.

- Formal small businesses that increased turnover over the last year, which was used as a survival variable, based on the fact that turnover stagnated or declined for small businesses after the recession period that started in 2008-2009 in South Africa.

Binary logistic regression was used with these two variables as dependent variables and the results are discussed below.

\section{Formal Small Businesses Older Than Five Years}

In assessing the model adequacy and fit, Table 4 sets out the information regarding the predictors included in the model, while Table 5 provides information regarding overall model fit. The number of respondents included in this combined model was 472 , as a case-wise removal process was used for missing data on any of the variables.

Table 4. Variables In The Equation

\begin{tabular}{lccrrrr}
\hline \multicolumn{1}{c}{ Predictors For Survival } & Beta Coefficient & S.E. & Wald & df & Sig. & Odds Ratio \\
\hline Education & .221 & .106 & 4.326 & 1 & .038 & 1.247 \\
Age (maturity) & .533 & .092 & 33.717 & 1 & .000 & 1.704 \\
Distance & .256 & .101 & 6.407 & 1 & .011 & 1.292 \\
Tracking & -.648 & .623 & 1.084 & 1 & .298 & .523 \\
Influence of local competitors & -.045 & .071 & .392 & 1 & .531 & .956 \\
Influence of large shopping malls & .149 & .079 & 3.525 & 1 & .060 & 1.161 \\
Constant & -3.129 & .903 & 11.997 & 1 & .001 & .044 \\
\hline
\end{tabular}

The overall correct prediction classification is $63.3 \%$

The results indicate that the independent variables of age/maturity and education of owner, as well as the distance from the large shopping malls, are statistically-significant predictors, at the $5 \%$ level of significance of business survival for a small business older than five years. The odds ratios indicate further that:

- $\quad$ Each increase in level of education increased the odds of business survival by $24.7 \%$. (Six levels of education were identified, namely: No schooling; Schooling Grade1 to Grade 3; Grade 4 to Grade 6; Grade 7 to 12; Technical/trade/training of less than 3 years and University/College/More than 3 years).

- $\quad$ Each increase in age category increased the odds of business survival by $70.4 \%$ (The six age groups categories were: 18 years or younger; 19 to 30 years; 31 to 40 years; 41 to 50 years; 51 to 60 years; and 61 years or older).

- $\quad$ Each increase in distance category away from the shopping malls increased the odds of business survival by $29.2 \%$. The four distance categories were: less than $1 \mathrm{~km} ; 1$ to $3 \mathrm{~km} ; 3.1$ to $5 \mathrm{~km}$ and more than $5 \mathrm{~km}$ ) 
Table 5. Model Summary

\begin{tabular}{cccc}
\hline Step & -2 Log likelihood & Cox \& Snell R Square & Nagelkerke R Square \\
\hline 1 & 601.959 & .105 & .140 \\
\hline
\end{tabular}

Hosmer And Lemeshow Test

\begin{tabular}{ccccc}
\hline Step & Chi-square & df & Sig. \\
\hline 1 & 11.088 & 8 & .197 & \\
\hline
\end{tabular}

The likelihood ratio test statistic in Table 5 above shows that the overall model is statistically significantly different from a model with only the constant term. The Hosmer and Lemeshow test shows non-significance indicating that the data fits the model fit well (Hosmer and Lemeshow, 2000). The $\mathrm{R}^{2}$ measures in this instance, however, is low and do indicate that follow-up studies is needed to validate and improve the current model.

\section{Formal Small Businesses That Grew Their Turnover Over The Last Year}

In assessing the model adequacy and fit, Table 6 sets out the information regarding the predictors included in the model while Table 7 provides information regarding overall model fit. The number of respondents included in this combined model was 472, as a case-wise removal process was used for missing data on any of the variables.

Table 6. Variables In The Equation

\begin{tabular}{lcccccc}
\hline \multicolumn{1}{c}{ Predictors For Survival } & Beta Coefficient & S.E. & Wald & df & Sig. & Exp(B) \\
\hline Education & .188 & .115 & 2.673 & 1 & .102 & 1.207 \\
Age (maturity) & .008 & .099 & .007 & 1 & .936 & 1.008 \\
Distance & .542 & .113 & 23.200 & 1 & .000 & 1.720 \\
Tracking & .805 & .650 & 1.534 & 1 & .216 & 2.238 \\
Influence of local competitors & -.011 & .080 & .020 & 1 & .889 & .989 \\
Influence of large shopping malls & -.622 & .101 & 37.665 & 1 & .000 & .537 \\
Age of the business & .257 & .106 & 5.862 & 1 & .015 & 1.293 \\
Constant & -2.525 & .950 & 7.064 & 1 & .008 & .080 \\
\hline
\end{tabular}

The overall correct prediction classification is $71.8 \%$.

The results indicate that the independent variables - age of the business, the distance from the large shopping malls and the extent of influence of large shopping malls - are statistically-significant predictors, at the 5\% level of significance of business growth (turnover growth in the last 12 months).

The odds ratios indicate further that:

- $\quad$ Each increase in distance category increased the odds of business turnover growth by $72 \%$ (four distance categories: less than $1 \mathrm{~km}$; 1 to $3 \mathrm{~km} ; 3.1$ to $5 \mathrm{~km}$; more than $5 \mathrm{~km}$ ).

- $\quad$ Each increase in the age group of the business increased the odds of business turnover growth by $29.3 \%$ (four age groups: less than 1 year; 1 year but less than 3 years; 3 years but less than 5 years; more than 5 years).

- $\quad$ Each decrease in the influence level of large shopping malls increased the odds of business turnover growth of formal small businesses by 1.86 (86\%). (A five-point scale was used, with one being 'not at all influenced' to five indicating 'an influence to a great extent').

Table 7. Model Summary

\begin{tabular}{cccc}
\hline Step & $\mathbf{- 2}$ Log likelihood & Cox \& Snell R Square & Nagelkerke R Square \\
\hline 1 & $520.284^{\mathrm{a}}$ & .240 & .320 \\
\hline
\end{tabular}

a. Estimation terminated at iteration number 4 because parameter estimates changed by less than .001 .

Hosmer And Lemeshow Test

\begin{tabular}{cccc}
\hline Step & Chi-square & df & Sig. \\
\hline 1 & 14.747 & 8 & .064 \\
\hline
\end{tabular}


The likelihood ratio test statistic in Table 7 shows that the overall model is statistically significantly different from a model with only the constant term. The Hosmer and Lemeshow test shows non-significance at the $5 \%$ level of significance, indicating that the data fit the model relatively well (Hosmer and Lemeshow, 2000). The $\mathrm{R}^{2}$ measures are above 0.2 , indicating a relatively good fit.

\section{Managerial Implications}

It is clear from the discussion above that there are certain trends that can be established from the research and the subsequent development of the model:

- It is clear that the longer the formal as well as non-formal small businesses have been in operation in Soweto, the better the chances for survival and turnover growth as described by Ligthelm (2010 and 2012) and Blackburn, Hart and Wainwright (2013).

- $\quad$ The test results indicate that $63.3 \%$ of the formal small businesses interviewed were correctly classified regarding the first survival variable (being in business for more than 5 years). The independent variables of higher qualifications, being more mature business owners and being further away from the large shopping malls are the key variables identified. This ties in with the findings of Ejembi and Ogiji (2007), Mbonyane and Ladzani (2011) and Nkosi and Bounds (2012).

- In the case where survival was defined as an increase in turnover of the past financial year, $71.8 \%$ of the formal small businesses were correctly classified. The independent variables of longevity of the business, the distance away from the large shopping malls and the lower influence of these shopping malls on their businesses were the key variables identified as the statistically-significant predictors.

- It can also be stated that, similar to the findings made by Ligthelm spanning a decade of research on the informal business sector, the following characteristics also play an important role in the continued survival and increase in turnover of formal small businesses in Soweto:

$\circ \quad$ The age of the business is a telling factor with a better chance of survival and increased turnover prospects.

- The physical location of these formal small businesses also plays an important role: being further away from the large shopping malls equates to having a better chance of survival.

$\circ \quad$ Education is also a significant factor. The higher the education levels of the owner of the formal small business, the better the chances of survival for these small businesses.

$\circ \quad$ The maturity (age) of the owner also plays a role. The more mature the owner is, the better the chances of survival for these formal small businesses.

The results of this study could therefore be used by owners/managers and financial institutions in their consideration for funding and expansion in the Soweto Township area.

\section{CONCLUSION}

In conclusion, it can be stated that there are major similarities in the survival profile of the informal and the formal businesses in the Soweto area. It is furthermore clear that the key survival characteristics, as indicated in the literature and identified by Ligthelm on the informal small businesses, are also applicable to the formal small businesses of Soweto. Even with the drastic changes in the business environment of the formal small businesses in Soweto, there were businesses which were able to survive and operate successfully. The large shopping malls did impact on the survival of these formal small businesses, but there is evidence that these businesses might be able to survive, given that owners/managers have certain characteristics such as operating an established business in a small existing shopping centre with ten or more stores, being further away from the large shopping malls and the large retailers, having a higher education level and being more mature in age. It is recommended that this type of research be replicated in other township areas of South Africa to better understand the impact of the Goliath shopping centres on the formal small business infrastructure that exists in the township areas. 


\section{AUTHOR INFORMATION}

Johan Strydom is a Professor in the Department of Business Management at the University of South Africa (Unisa). He holds a DCom degree in Business Management and has been lecturing at Unisa for 35 years. His research interests include business management, small business management, distribution management, retailing and supply chain management. Email: strydjw@unisa.ac.za.

\section{REFERENCES}

Abrahams, C. (2009). Transforming the region: supermarkets and the local food economy. African Affairs, volume 109/493,115-134.

Berner, E, Gomez, G and Knorringa, P. (2008). Helping a large number of people becoming a little less poor: The logic of survival entrepreneurs. Paper presented at the University of the UN, Helsinki: 21-23 August.

Blackburn, RA, Hart, M and Wainwright, T. (2013). Small business performance: business, strategy and ownermanager characteristics. Journal of small business and enterprise development, vol. 20, no. 1: 8-27.

Burger, S. (2013). Black middle class: aspirational and on the move. (2014) [Online] Available: http://themediaonline.co.za/2013/05/black-middle-class-aspirational-and-on-the-move/(May 30, 2014).

Butler, C. (1989). The extent and nature of black business development. LS Associates, Sandton.

Chiliya, N., Herbst, G. and Roberts-Lombard, M. (2009). 'The impact of marketing strategies on profitability of small grocery shops in South African townships', African Journal of Business Management, 3(3): 70-79.

Du Plessis, PJ, Strydom, JW and Jooste, CJ. (2012). Marketing Management (6th edition). Cape Town, Juta.

Ejembi, S.A. and Ogiji, P. (2007). "A comparative analysis of risks and returns of running small/medium and micro enterprises in North and Central Nigeria", Journal of Social Science, vol. 15, no. 1, 7-15.

Gilbert, D. (2003). Retail Marketing Management, 2nd ed. Harlow: Financial Times Prentice Hall.

Giliomee J (2004). The small business environment. Entrepreneurial Business School. [Online] Available:http://ebschool.com/wpcontent/uploads/2009/07/ The_Small_Business_Environment.pdf (July 12, 2012).

Hosmer, D.W., \& Lemeshow, S. (2000). Applied logistic regression, $2^{\text {nd }}$ ed. Hoboken NJ: John Wiley and Sons.

Ihua, U.B. (2009). SMEs key failure-factors: a comparison between the United Kingdom and Nigeria, Journal of Social Science, vol. 18, no. 3, 199-207.

Levy, M and Weitz, BA. (2012). Retailing Management (8th ed.). New York: McGraw-Hill/Irwin.

Ligthelm AA, (2004). Profile of informal microenterprises in the retail sector of South Africa. Southern African Business Review, volume 8, no. 1, 39-53.

Ligthelm, AA. (2005). Informal retailing through home-based micro-enterprises: The role of spaza shops. Development Southern Africa. Vol. 22 (2), 199-214.

Ligthelm, AA. (2006). Size estimate of the informal sector in South Africa. South African Business Review, vol. 10 (2), 32-52.

Ligthelm, A.A. (2008). The impact of shopping mall development on small township retailers, South African Journal of Economic and Management Sciences, 11(1). 37-53.

Ligthelm, AA. (2010). Entrepreneurship and small business sustainability. Southern African Business Review Volume 14 (3), 131-151.

Ligthelm, AA. (2012). The viability of informal micro businesses in South Africa: A longitudinal analysis (2007 to 2011). African Journal of Business Management, vol.6 (46), 11416-11425.

Ligthelm, A.A. (2013). Confusion about entrepreneurship? Formal versus informal small businesses. Southern African Business Review, volume 17, no. 3, 57-75.

Makholwa, A. (2014). Township Economy: room for small and mall. [Online] Available: http://www.financialmail.co.za/features/2014/09/18/township-economy-room-for-small-and-mall (September 18, 2014).

Mbonyane, B and Ladzani. W. (2011). Factors that hinder the growth of small businesses in South African townships. European Business Review, vol. 23, no. 6, 550-560.

Moodie, G. (2003). Education is the missing link, Sunday Times Business Times, 30 March, 1.

National Small Business Amendment Act of the Republic of South Africa. (2003). Pretoria Government Printer. (no. 26)

Naude W. (2009). Out of the sleaze, in with the ease. Research Paper 2009/01. Helsinki: United Nations University, 


\section{UNU-WIDER.}

Nkosi and Bounds (2012). Working papers, Centre for Small Business Development: Faculty of Management, UJ, 3rd annual international conference: growing industries in townships and under-developed neighbourhoods. Editors, Mazwai, T \& Esther, N. [Online] Available:http://csbd.co.za/documents/2012-CSBD-ConferenceProceedings. pdf\#page $=236$, (April 20, 2013).

Okpara, JO. (2011). "Factors constraining the growth and survival of SMEs in Nigeria: Implications for poverty alleviation", Management Research Review, vol. 34 (2), 156 - 171.

Reijonen, H and Komppula, R. (2007). "Perception of success and its effect on small firm performance", Journal of Small Business and Enterprise Development, vol. 14 (4), 689 - 701.

Strydom, JW. (2005). Tracking study on skills development and employment generation of small retail establishments in Mamelodi, Tshwane. Southern African Business Review, volume 9, no. 3, 15-22.

Strydom, JW. (2011). Retailing In Disadvantaged Communities: The Outshopping Phenomenon Revisited. Journal of Contemporary Management, vol. 8. 150-172.

Strydom, JW, Martins, JH, Potgieter, M and Geel, M. (2002).The retailing needs of a disadvantaged community in South Africa. South African Business Review, vol.6 (1)18.

Thomas White global investing: Emerging market spotlight. (2011). Retail in South Africa: making an impression. [Online] Available http://www.thomaswhite.com/pdf/emerging-markets-spotlight-south-africa-consumergoods-july-2011.pdf. (April 11, 2013).

Tushabomwe-Kazooba, C (2006). "Causes of Small Business failure in Uganda: A Case Study from Bushenyi and Mbarara Towns" African Studies Quarterly 8, no.4: 27-35.

Tustin, DH and Strydom, JW. (2006). The potential impact of formal retail chains' expansion strategies on retail township development in South Africa. South African Business Review, vol. 10, no 3, 48 - 66.

Vallie, A. 2012. Retailers' push into townships crushes Metcash. [Online] Available: http://www.bizcommunity.com/Article/196/182/76426.html (April 11, 2013).

Van Eeden, S., Viviers, S. and Venter, D. (2003). `A comparative study of selected problems encountered by small businesses in the Nelson Mandela, Cape Town and Egoli Metropoles', Management Dynamics, 12(3), 13.

Van Scheers, L. (2010).Challenges of small family grocery shops in South Africa. World Journal of Entrepreneurship, Management and Sustainable Development, vol. 6, no. 3, 221-231.

Woodward, D, Rolfe, R, Ligthelm, AA and Guimarães, P. (2011). The viability of informal microenterprise in South Africa. Journal of Developmental Entrepreneurship vol. 16, no. 1, (2011) 65-86. 


\section{NOTES}

